\title{
Rankings in the Eyes of the Beholder: A Vox Populi Approach to Academic Journal Ranking
}

\author{
Kim-Shyan Fam \\ Victoria University of Wellington \\ Paurav Shukla \\ University of Brighton \\ Ashish Sinha \\ University of New South Wales \\ Chung-Leung Luk \\ City University of Hong Kong \\ Mathew Parackal \\ University of Otago \\ Joe Choon Yean Chai \\ University of Otago
}

\begin{abstract}
The ranking of academic journals is a contentious issue in the current higher education environment. Across the world, peers judge academics for tenure and promotion on the basis of the quality or prestige of the journals in which they publish. This research proposes a new metric (i.e., the MAG score) to assess journal impact and ranking in the field of marketing using the vox populi approach. The findings show that the vox populi approach provides a more comprehensive measure of journal impact than other impact factor metrics from the perspective of academics.
\end{abstract}

Keywords: Journal rankings, Perceptions, Impact factor, Marketing journals, Vox populi 


\section{Introduction}

Most organizations, be they academic or corporate, use various kinds of metrics to assess their progress. However, during the past two decades, the academic discipline has experienced a phenomenal increase in the use of and reliance on various ranking metrics for recruiting and promoting academics and researchers. A growing competition exists among researchers, academic institutions, and journals to achieve high rankings (Bakir et al., 2000; Dibb and Simkin, 2005; Macdonald and Kam, 2007; Mort et al., 2004). As Rynes (2007) observes, publication in major journals significantly influences academic hiring, tenure, and promotion decisions. Citation impact has also become an important measure for evaluating senior academics in academic institutions (Adler and Harzing, 2009; Saad, 2009).

Such measures have a long-term impact on individual and institutional policy for research. For example, as Rynes (2007) notes, individuals and institutions focusing too heavily on these metrics have a very narrow definition of research productivity, which focuses on counting publications in high-impact-factor journals along with citations in the limited set of journals that such ranking systems recognize. Segalla (2008) further observes that such narrow definitions slow the diffusion of ideas and stifle academic dialogue because academics tend not to focus on other specialist journals with lower citation impact.

Rynes (2007) emphasizes that journal publications count highly toward academic promotions in the United States, and a similar trend occurs in the Asian context. Lawrence (2003, p. 259) observes, "scientists are increasingly desperate to publish in a few top journals and are wasting time and energy manipulating their manuscripts and courting editors. As a result, the objective presentation of work, the accessibility of articles, and the quality of research itself are being compromised."

Adler and Harzing (2009) opine that many academic researchers are involved in developing highly esoteric manuscripts that have questionable contribution in advancing the overall social understanding (Perren et al., 2001).

In their examination of international business journal rankings, Adler and Harzing (2009) find that competing rankings were arbitrary and no consensus exists among researchers on the superiority of any specific ranking approach. Therefore, Adler and Harzing called for an immediate examination of existing ranking systems, suggesting that the current academic assessment systems undermine rather than foster or reward scholarship that matters. To address the calls for research in this area, this article attempts to fill the gap in the literature. A distinguishing feature of this work is the use of the vox populi (Latin for "voice of the people") approach to address the issues raised in the context of academic journal rankings.

Surowiecki (2004) argues that a diverse collection of independently deciding individuals is likely to make certain types of decisions and predictions better than individuals or even experts. Surowiecki outlines four important elements for outlining a wise crowd: (1) diversity of opinion, (2) independence, (3) decentralization, and (4) aggregation. Many scholars believe that the academic community in general possesses 
these elements, and therefore the vox populi approach may capture the "wisdom of the crowds." To enhance the overall approach, the current research also uses the "topof-the-mind" recall method, which the field of advertising research frequently employs.

This study contributes to the understanding of how marketing academics across the academic spectrum (i.e., from lecturers to professors) rank academic journals and also demonstrates the prevalent trend in publishing among marketing scholars. The study also examines the range of marketing academic publications and highlights whether marketing academics' approach to publication is becoming significantly marginalized within marketing-related journals. In addition, the study helps identify whether regional differences exist in relation to publication preference. Prior research has observed that the elite of the academic profession, who may not represent the total academic population, created most of the other ranking indices (Theoharakis and Hirst, 2002; Van Fleet et al., 2000). By taking into consideration views from a wide spectrum of academics, this study provides a much more balanced view related to academic journal rankings. Finally, this study examines whether perceptions of journal quality match independent and more objective assessments of the impact of journals.

\section{Background}

Several methods that evaluate and rank journals exist; however, each has its own merits and demerits. For example, the scientific community widely uses the impact factor method (Rynes, 2007; Saad, 2009; Segalla, 2008). However, quite a few articles and commentaries have identified inherent problems with the impact factor (Hascall et al., 2007; Kirkpatrick and Locke, 1992; Lange, 2006; Perren et al., 2001). For example, (1) long articles collect many citations and, on average, receive a higher journal impact factor than short articles; (2) journals with a short publication lag allow many short-term journal citations and thus receive a higher journal impact factor; (3) new and specialized journals tend to be excluded from the impact factor; (4) no correlation exists between an individual's journal articles and the journal impact factor; and (5) authors tend to over-cite themselves (Guerrero, 2002).

Kacmar and Whitfield (2000) identify several inherent problems with journal rankings. They suggest that the problem arises because of the generalization in rankings, as each citation is awarded equal weight. This means that an article cited in a "laundry list of references would be given the same impact score as an article that develops a complete research sty around the previous research" (Kacmar and Whitfield, 2000, p. 395). The impact factor does not include a negative citation measure, in which the work has been criticized for the shortcomings. The citation index can also be skewed depending on the journal in which an academic wishes to publish and the popularity of certain authors in the field.

Researchers suggest the use of various methods to avoid the inherent bias in journal rankings. The "perceived quality" of journals is one of the methods used to assess the 
merit of articles published by academics (Theoharakis and Hirst, 2002). Although this method is widely accepted, a panel of senior academics collates perceived quality journal lists, as in the case of the Australian Business Deans Journal List or the Association of Business Schools' Academic Journal Quality Guide. The intent of both these lists is to assist promotion/hiring committees and allow review teams to evaluate the quality of the research output of academics.

In New Zealand, although no such "official" list exists, the panel members of the last two PBRF (Performance Based Research Fund) exercises used a combination of recognized perceived quality lists to evaluate academics' research output. However, a point of contention raised against the perceived quality method is that the list is heavily biased toward those on the panel, as Cudd and Morris (1988) show in their study; here, they observe that respondents who published in top journals tended to give low merit points to low-ranked journals. The tendency also exits to grant a higher grade to journals in which a person him- or herself has published (see Extejt and Smith, 1990; Jobber and Simpson, 1988; Todorov and Glanzel, 1988). Van Fleet et al., (2000) claim that if a panel comprises professors and senior academics that have considerable top journal publications, new and upcoming journals are disadvantaged from developing into quality journals because they are ignored. This disadvantageous positioning may then extend to academics who publish in such journals. Thus, the use of panels to create journal rating lists may be subject to self-preservation and predisposition bias.

Another method involves collecting rating scores from a sample of academics using survey research. The biases discussed when using a panel could still surface in this method, but with a lesser magnitude. Anchors used in the survey questionnaire, which may not reflect the content quality of the journals, introduce a serious bias. Other biases include item order effect and respondent fatigue. Although item order effect can be controlled through randomization, respondent fatigue may be difficult to control because respondents must rate a large number of journals at the same time. For example, in their study, Mort et al. (2004) use a list of 73 journals.

Another concern is that the journal list used in such rating exercises often is recycled from similar studies or contained journals that the researchers believe are appropriate. In either case, the respondents have no input in the creation of the journal list. For institutions, the journal ranking list affects the funding that the institution receives, and for academics, the ranking list plays a major role in their career advancement. Therefore, producing a rating list that is free of bias is imperative.

\section{Methodology}

The current study approach is to allow academics the freedom to nominate as many journals as they can recall in a given category. Thus, through unaided recall, top-ofthe-mind awareness of a journal among the academics was produced. This established method is used extensively in measuring advertisement effectiveness and brand recall. In the current case, this method is used to assess the awareness of A-, B-, and C-grade 
journals among academics. The advantage of unaided recall lies in the requirement for mental processing of retrieving the stored encoded information without any cues (see Bagozzi and Silk, 1983; Finn, 1992; Krugman, 1986; Shapiro and Krishnan, 2001; Stapel, 1998; Till and Baack, 2005). Such an approach would embody more credibility to the journal ranking list given that academics are responsible for generating and disseminating knowledge and, in the process, have seen, read, and/or published in the journals they nominate.

\section{Sampling Approach}

The sampling approach used was based on the vox populi notion of Galton (1907), which suggests that the intelligence of the masses far exceeds that of any single individual or of experts. According to the vox populi theory, any judgment respondents make will be free of passion and uninfluenced by rhetoric. Galton (1907, p. 451) claims that the result derived from vox populi is "correct to within 1 percent of the true value and more creditable to the trustworthiness of a democratic judgment than might have been expected." To implement the vox populi sampling approach, this study developed a sampling frame of academics by scanning marketing, tourism, and international business departmental web sites of universities across the five continents.

For countries such as Singapore, Taiwan, Korea, Malaysia, Canada, the United Kingdom, the Republic of Ireland, Australia, New Zealand, and Hong Kong, the sample included academics in marketing/tourism/international business departments of all the universities in the respective countries. For the United States, in addition to including the top 500 universities based on the Shanghai Jiao Tong Academic Ranking of World Universities List 2007 (ARWU), the sample included another 200 universities not in this list. For continental Europe, Japan, India, Africa, the Middle East, and South America, the sample included universities that were listed in both the Shanghai Jiao Tong ARWU and THES-QS World University Rankings 2007, plus an additional 200 universities not listed in either of these two lists.

The survey included academics from all levels (lecturers, senior lecturers, assistant professors, associate professors, professors, and chair professors). In total, 5336 academics from the five continents were approached through their e-mail address. Of these, 425 out-of office auto-generated messages, 390 "undeliverable" e-mails (e.g., invalid e-mail addresses), and 232 responses deemed incomplete could not be used. The survey successfully captured data from 538 academics who indicated the journals they believed were A, B, and C grade. The collective data of the 538 academics were compiled to produce a list titled "The MAG Scholar List." MAG Scholar is the abbreviation for the Marketing in Asia Group (www.magscholar.com), which initiated the study. This group is an association of researchers from all walks of academia with research interest in Asia and residing in 35 countries. 


\section{Questionnaire Design}

The questionnaire was divided into two sections. In the first section, respondents nominated up to 10 perceived A-grade journals, including the journals the respondents had published in between 2003 and 2008. Following the nomination of A-grade journals, the next step was to nominate the B-grade and C-grade journals in which the respondents had published. A six-year time frame was deemed appropriate in an attempt to adequately capture the breadth of the respondents' publications. The second section captures the demographic profile of the respondents. This profile includes respondents' highest academic qualification; the country in which they obtained their degree; the percentage of teaching and research activities devoted to marketing, tourism, and international business; affiliation; and gender.

\section{Results}

\section{Demographic Profile}

The total number of respondents who completed the online survey was 538. The majority $(73.4 \%)$ of the respondents was male, and roughly $74 \%$ of the respondents held a doctoral degree. On the question of teaching and research activities, most of the respondents claimed marketing (76\%), followed by international business $(15 \%)$ and tourism (9\%). Respondent affiliation profiles showed that the highest number of respondents were affiliated with the American Marketing Association (36.6\%), followed by the European Marketing Academy (18.4\%). The smaller groups such as the Australia New Zealand Marketing Academy, Industrial Marketing and Purchasing, and MAG Scholar registered less than $10 \%$ of respondents. The majority of the respondents were from U.S./Canada (41.3\%), U.K./Europe (26.3\%), Australia/New Zealand (21.2\%), and Asia/Africa (11.2\%). In total, 30 countries were represented in this study.

\section{Perceived A-grade Refereed Journals}

The 538 respondents recalled 364 different so-called A-grade journals. The range in number of unaided recalls was from a low of one to a high of 10 journals. Six journals had more than 100 unaided recalls, eight journals had between 50 and 99 unaided recalls, and 16 journals had between 25 and 49 unaided recalls. The remaining journals had less than 25 unaided recalls. Journal of Marketing had the highest number of unaided recalls, occupying $9 \%$ of the share of voice. Journal of Marketing Research (347) was next, with a share of voice of $8 \%$. Of the 364 different A-grade journals, the respondents had published in only $20.4 \%$ of them since 2003 . The low publication rate would further support this study's unbiased results compared with other similar studies in which responses were usually heavily contaminated by respondents who had an interest in the journals. 
Regionally, Journal of Marketing and Journal of the Academy of Marketing Science were the most-published outlet for academics from the United States and Canada (frequency $=7.7 \%$ ). The academics from Australia and New Zealand published mainly in Journal of Marketing (5.9\%), Marketing Science (5.9\%), and Journal of Business Research (5.5\%). European and U.K. academics published in Journal of Marketing (7.1), Journal of Consumer Research (5.7), and Journal of Business Research (5.3\%). Finally, Asian academics preferred journal outlets such as Journal of Business Research (7.8\%) and Journal of the Academy of Marketing Science (7.8\%), followed by European Journal of Marketing (6.5\%).

The journals in which respondents published the most are primarily marketing related; however, the journals in which respondents published the least show an interesting trend. Among the U.S. and Canadian academics, the least-published outlets were Academy of Management Journal (frequency $=0.4 \%$ ), Academy of Management Review (0.4\%), Harvard Business Review (0.4\%), and Administrative Science Quarterly $(0.4 \%)$. A similar trend occurred across the sample. Although the aforementioned journals are highly ranked according to their impact factor scores, marketing academics did not publish in them. This trend also highlights the increasing divide between marketing- and non-marketing-oriented journals. With a fewer number of academics preferring to publish in these journals, the divide may grow larger in the future.

\section{Determining MAG Score and Index}

To determine whether the perceived journal quality list matches the more abstract bibliometric indices, this study undertook compilation of the MAG Scholar Journal List. The list included the total unaided recalls of A-, B-, and C-grade journals. This study combined all three grade journals because most of the journals in the A-grade list included B- and C-grade journals. In addition, this study intended to produce a list generated by the respondents based on the total number of unaided recalls for each journal. A combined high recalls reflect the importance of the journal. After "cleanup," which included deleting repeated entries for the same journal in each unaided recall and journals that were marginally unrelated to the business and management discipline, the total number of journals dropped to a manageable list. Because each journal has own features and merits, the first unaided recalled journal was allocated more weight than the second, third, fourth, and so on, until the tenth position. The study designed a formula to capture the relative standing of these journals. The sum of each journal's value was labeled MAG score, and this score was used to rank the journal relative to the others.

$$
\text { MAG score }=\sum \mathrm{n}\left(\mathrm{X}_{\mathrm{in}} / \mathrm{T}_{\mathrm{n}}\right) \times(1 / \mathrm{n})
$$

Where $\mathrm{x}$ is the number of unaided recalls, $\mathrm{i}$ is the type of journal, $\mathrm{n}$ is the order of journal recalls $(\mathrm{n}=1,2,3, \ldots, 10)$, and $\mathrm{T}$ is the total number of journal recalls. 
As Table 1, Column 4, shows, Journal of Marketing has a MAG score of 0.4168 and a MAG index of 100. Journal of Marketing Research is next with a MAG index of $60.94(0.2540 / 0.4168)$. The "Difference" column indicates the MAG score difference between Journal of Marketing (0.4168) and Journal of Marketing Research (0.2540) multiplied by 1000 . The use of 1000 is to amplify the difference. Using the figures in the "Difference" column (Column 6), the study scientifically identified a "break" between a group of high AAA-grade journals and the second-best group. For example, a significant break occurs between Journal of the Retailing (11.30) and Journal of International Business Studies, between Academy of Management Journal (9.78) and Academy of Management Review (0.05), and between Journal of Travel Research (2.10) and Journal of International Marketing (0.80). Overall, the study identified six AAA-rated, eight AAB-rated, and 15 ABB-rated journals. This statistically derived difference suggests a large distinction among the AAA-, AAB-, ABB-, and BBB-ranked journals.

Table 1 MAG Score and Index of Top 30 Journals

\begin{tabular}{|c|c|c|c|c|c|c|}
\hline Rank & Journal & $\begin{array}{c}\text { Total } \\
\text { Recalls }\end{array}$ & $\begin{array}{l}\text { MAG } \\
\text { Scores }\end{array}$ & $\begin{array}{l}\text { MAG } \\
\text { Index }\end{array}$ & Difference & Group \\
\hline 1 & Journal of Marketing & 394 & 0.4168 & 100.00 & 162.78 & AAA \\
\hline 2 & Journal of Marketing Research & 347 & 0.2540 & 60.94 & 47.92 & AAA \\
\hline 3 & Journal of Consumer Research & 305 & 0.2061 & 49.44 & 64.68 & AAA \\
\hline 4 & Marketing Science & 242 & 0.1414 & 33.92 & 61.33 & AAA \\
\hline 5 & $\begin{array}{l}\text { Journal of the Academy of } \\
\text { Marketing Science }\end{array}$ & 178 & 0.0800 & 19.20 & 22.09 & AAA \\
\hline 6 & Journal of Retailing & 125 & 0.0580 & 13.91 & 11.30 & AAA \\
\hline 7 & $\begin{array}{l}\text { Journal of International Business } \\
\text { Studies }\end{array}$ & 67 & 0.0467 & 11.19 & 2.69 & $\mathrm{AAB}$ \\
\hline 8 & European Journal of Marketing & 76 & 0.0440 & 10.55 & 1.22 & $\mathrm{AAB}$ \\
\hline 9 & Journal of Business Research & 82 & 0.0427 & 10.26 & 1.77 & $\mathrm{AAB}$ \\
\hline 10 & $\begin{array}{l}\text { International Journal of Research } \\
\text { in Marketing }\end{array}$ & 89 & 0.0410 & 9.83 & 1.40 & $\mathrm{AAB}$ \\
\hline 11 & Management Science & 74 & 0.0396 & 9.50 & 0.96 & $\mathrm{AAB}$ \\
\hline 12 & Annals of Tourism Research & 43 & 0.0386 & 9.27 & 0.83 & $\mathrm{AAB}$ \\
\hline 13 & Journal of Advertising & 67 & 0.0378 & 9.07 & 0.68 & $\mathrm{AAB}$ \\
\hline 14 & $\begin{array}{l}\text { Academy of Management } \\
\text { Journal }\end{array}$ & 51 & 0.0371 & 8.90 & 9.78 & $\mathrm{AAB}$ \\
\hline 15 & $\begin{array}{l}\text { Academy of Management } \\
\text { Review }\end{array}$ & 38 & 0.0273 & 6.56 & 0.05 & $\mathrm{ABB}$ \\
\hline 16 & Journal of Consumer Psychology & 53 & 0.0273 & 6.55 & 0.51 & ABB \\
\hline
\end{tabular}




\begin{tabular}{|c|c|c|c|c|c|c|}
\hline Rank & Journal & $\begin{array}{c}\text { Total } \\
\text { Recalls }\end{array}$ & $\begin{array}{l}\text { MAG } \\
\text { Scores }\end{array}$ & $\begin{array}{l}\text { MAG } \\
\text { Index }\end{array}$ & Difference & Group \\
\hline 17 & International Marketing Review & 34 & 0.0268 & 6.42 & 0.09 & $\mathrm{ABB}$ \\
\hline 18 & Tourism Management & 35 & 0.0267 & 6.40 & 0.99 & $\mathrm{ABB}$ \\
\hline 19 & Journal of Consumer Behaviour & 28 & 0.0257 & 6.17 & 0.07 & $\mathrm{ABB}$ \\
\hline 20 & Marketing Letters & 28 & 0.0256 & 6.15 & 0.76 & $\mathrm{ABB}$ \\
\hline 21 & Journal of Advertising Research & 47 & 0.0249 & 5.96 & 1.27 & $\mathrm{ABB}$ \\
\hline 22 & Journal of Services Marketing & 30 & 0.0236 & 5.66 & 0.50 & $\mathrm{ABB}$ \\
\hline 23 & Strategic Management Journal & 40 & 0.0231 & 5.54 & 1.62 & $\mathrm{ABB}$ \\
\hline 24 & Harvard Business Review & 34 & 0.0215 & 5.15 & 0.90 & $\mathrm{ABB}$ \\
\hline 25 & $\begin{array}{l}\text { Industrial Marketing } \\
\text { Management }\end{array}$ & 37 & 0.0206 & 4.94 & 0.33 & $\mathrm{ABB}$ \\
\hline 26 & Administrative Science Quarterly & 30 & 0.0202 & 4.86 & 0.20 & $\mathrm{ABB}$ \\
\hline 27 & Journal of Service Research & 40 & 0.0200 & 4.81 & 0.61 & $\mathrm{ABB}$ \\
\hline 28 & $\begin{array}{l}\text { Journal of Marketing } \\
\text { Management }\end{array}$ & 33 & 0.0194 & 4.66 & 2.10 & $\mathrm{ABB}$ \\
\hline 29 & Journal of Travel Research & 24 & 0.0173 & 4.16 & 2.10 & $\mathrm{ABB}$ \\
\hline 30 & $\begin{array}{l}\text { Journal of International } \\
\text { Marketing }\end{array}$ & 30 & 0.0152 & 3.65 & 0.80 & BBB \\
\hline
\end{tabular}

Note: For a full listing, please see www.magscholar.com.

\section{Validation of MAG Score}

To further validate the MAG score, this study carried out a correlation test with SSCI and Scopus indices. Primarily, the goal of the comparison is to identify whether similarity exits between the MAG score and the more widely known and established assessments of the impact of journals. Thomson's ISI Web of Knowledge (SSCI) and Elsevier's Scopus database have approximately 2470 and 2850 social sciences titles, respectively. The citation index measures the number of times authors cite an average article in a journal in related journals. Both indices provide a proxy for the quality of an article/journal.

To compare the MAG score with the SSCI and Scopus indices, the study compiled a MAG Scholar List of the top 100 journals. This list was used to identify similar journals indexed in SSCI and Scopus. In total, SSCI and Scopus have 44 and 74 journals that appeared in the top 100 MAG Scholar List, respectively. Then, all the 2009 articles (N) that appeared in each of these journals were counted. Also identified 
was the impact article citation index (I) for each journal. Next, the number of articles was multiplied by the citation index $(\mathrm{N} \times \mathrm{I})$ to estimate the total annual citation impact factor (TIF) for each journal. After identifying the total impact factor (TIF) for each journal, the study conducted a correlation analysis to find the overall similarity among SSCI, Scopus, and the MAG score. The correlation between Scopus and the MAG score was significant $(\mathrm{r}=0.488, p<0.001)$. A strong and significant correlation was found for the top 20 journals $(r=0.420, p<0.001)$. This analysis indicates that the MAG Scholar List is similar to the broadly defined Scopus index. The significant correlation implies that perceptions match independent, more objective assessments of the impacts of journals. However, no significant correlation appeared between the SSCI and the MAG score. This could be due to SSCI's narrower business and management database.

Table 2 Comparison between MAG Score, SSCI and SCOPUS Indices

\begin{tabular}{|c|c|c|c|c|c|c|c|c|c|c|}
\hline No. & Journal Name & $\begin{array}{c}2009 \\
\text { Publn }\end{array}$ & $\begin{array}{c}\text { Scopus } \\
\text { IF }\end{array}$ & $\begin{array}{l}\text { Scopus } \\
\text { TIF }\end{array}$ & $\begin{array}{c}\text { Scopus } \\
\text { Rank } \\
\text {-ing }\end{array}$ & $\begin{array}{c}\text { SSCI } \\
\text { IF }\end{array}$ & $\begin{array}{l}\text { SSCI } \\
\text { TIF }\end{array}$ & $\begin{array}{c}\text { SSCI } \\
\text { Rank } \\
\text {-ing }\end{array}$ & $\begin{array}{l}\text { MAG } \\
\text { Score }\end{array}$ & $\begin{array}{l}\text { MAG } \\
\text { Rank } \\
\text {-ing }\end{array}$ \\
\hline 1 & Journal of Marketing & 62 & 4.23 & 262.36 & 10 & 4.10 & 253.89 & 4 & 0.417 & 1 \\
\hline 2 & $\begin{array}{l}\text { Journal of Marketing } \\
\text { Research }\end{array}$ & 77 & 2.58 & 198.65 & 6 & 2.57 & 198.20 & 22 & 0.254 & 2 \\
\hline 3 & $\begin{array}{l}\text { Journal of Consumer } \\
\text { Research }\end{array}$ & 78 & 1.60 & 124.55 & 25 & 1.59 & 124.18 & 61 & 0.206 & 3 \\
\hline 4 & Marketing Science & 88 & 2.41 & 212.12 & 19 & 3.31 & 291.19 & 9 & 0.141 & 4 \\
\hline 5 & $\begin{array}{l}\text { Journal of the } \\
\text { Academy of } \\
\text { Marketing Science }\end{array}$ & 41 & 2.25 & 92.39 & 75 & 1.29 & 52.85 & 76 & 0.080 & 5 \\
\hline 6 & Journal of Retailing & 45 & 3.91 & 175.91 & 49 & 4.10 & 184.28 & 4 & 0.058 & 6 \\
\hline 7 & \begin{tabular}{|l|} 
Journal of \\
International Business \\
Studies
\end{tabular} & 93 & 2.62 & 243.70 & 41 & 2.99 & 278.26 & 12 & 0.047 & 7 \\
\hline 8 & $\begin{array}{l}\text { European Journal of } \\
\text { Marketing }\end{array}$ & 76 & 1.04 & 79.17 & 283 & 0.71 & 54.11 & 132 & 0.044 & 8 \\
\hline 9 & $\begin{array}{l}\text { Journal of Business } \\
\text { Research }\end{array}$ & 172 & 1.28 & 220.34 & 127 & 0.94 & 162.20 & 108 & 0.043 & 9 \\
\hline 10 & $\begin{array}{l}\text { International Journal } \\
\text { of Research in } \\
\text { Marketing }\end{array}$ & 39 & 1.81 & 70.60 & 71 & 1.61 & 62.83 & 60 & 0.041 & 10 \\
\hline 11 & Management Science & 141 & 2.69 & 379.89 & 31 & 2.35 & 331.91 & 29 & 0.040 & 11 \\
\hline 12 & $\begin{array}{l}\text { Annals of Tourism } \\
\text { Research }\end{array}$ & 40 & 1.70 & 68.00 & 126 & 1.10 & 44.16 & $\mathrm{Z}$ & 0.039 & 12 \\
\hline 13 & Journal of Advertising & 34 & 0.94 & 32.07 & 154 & 1.00 & 34.00 & 102 & 0.038 & 13 \\
\hline 14 & $\begin{array}{l}\text { Academy of } \\
\text { Management Journal }\end{array}$ & 63 & 5.50 & 346.31 & 9 & 6.08 & 382.98 & 2 & 0.037 & 14 \\
\hline 15 & $\begin{array}{l}\text { Academy of } \\
\text { Management Review }\end{array}$ & 43 & 6.19 & 266.13 & 21 & N/A & $\mathrm{N} / \mathrm{A}$ & $\mathrm{X}$ & 0.027 & 15 \\
\hline 16 & \begin{tabular}{|l} 
Journal of Consumer \\
Psychology
\end{tabular} & 69 & 2.26 & 156.07 & $\mathrm{Z}$ & 2.84 & 196.03 & 16 & 0.027 & 16 \\
\hline
\end{tabular}




\begin{tabular}{|c|c|c|c|c|c|c|c|c|c|c|}
\hline No. & Journal Name & $\begin{array}{c}2009 \\
\text { Publn }\end{array}$ & \begin{tabular}{|c|} 
Scopus \\
IF
\end{tabular} & $\begin{array}{c}\text { Scopus } \\
\text { TIF }\end{array}$ & $\begin{array}{c}\text { Scopus } \\
\text { Rank } \\
\text {-ing }\end{array}$ & $\begin{array}{c}\text { SSCI } \\
\text { IF }\end{array}$ & $\begin{array}{l}\text { SSCI } \\
\text { TIF }\end{array}$ & $\begin{array}{c}\text { SSCI } \\
\text { Rank } \\
\text {-ing }\end{array}$ & $\begin{array}{l}\text { MAG } \\
\text { Score }\end{array}$ & $\begin{array}{c}\text { MAG } \\
\text { Rank } \\
\text {-ing }\end{array}$ \\
\hline 17 & $\begin{array}{l}\text { International } \\
\text { Marketing Review }\end{array}$ & 32 & 1.33 & 42.50 & 246 & 1.16 & 37.25 & 84 & 0.027 & 17 \\
\hline 18 & Tourism Management & 91 & 1.81 & 164.47 & 134 & 1.27 & 115.93 & 77 & 0.027 & 18 \\
\hline 19 & $\begin{array}{l}\text { Journal of Consumer } \\
\text { Behaviour }\end{array}$ & 28 & $\mathrm{~N} / \mathrm{A}$ & $\mathrm{N} / \mathrm{A}$ & $\mathrm{Z}$ & $\mathrm{N} / \mathrm{A}$ & $\mathrm{N} / \mathrm{A}$ & $\mathrm{X}$ & 0.026 & 19 \\
\hline 20 & Marketing Letters & 22 & 0.74 & 16.38 & 101 & 0.70 & 15.36 & 135 & 0.026 & 20 \\
\hline 21 & $\begin{array}{l}\text { Journal of Advertising } \\
\text { Research }\end{array}$ & 34 & 0.54 & 18.48 & 235 & 0.61 & 20.81 & 144 & 0.025 & 21 \\
\hline 22 & $\begin{array}{l}\text { Journal of Services } \\
\text { Marketing }\end{array}$ & 46 & 0.86 & 39.66 & 272 & $\mathrm{~N} / \mathrm{A}$ & $\mathrm{N} / \mathrm{A}$ & $\mathrm{X}$ & 0.024 & 22 \\
\hline 23 & $\begin{array}{l}\text { Strategic Management } \\
\text { Journal }\end{array}$ & 72 & 3.32 & 239.12 & 32 & 3.34 & 240.77 & 8 & 0.023 & 23 \\
\hline 24 & $\begin{array}{l}\text { Harvard Business } \\
\text { Review }\end{array}$ & 286 & 0.81 & 230.85 & 38 & 1.79 & 512.80 & 47 & 0.021 & 24 \\
\hline 25 & $\begin{array}{l}\text { Industrial Marketing } \\
\text { Management }\end{array}$ & 107 & 1.77 & 189.86 & 133 & 1.40 & 150.12 & 70 & 0.021 & 25 \\
\hline 26 & $\begin{array}{l}\text { Administrative } \\
\text { Science Quarterly }\end{array}$ & 14 & 1.83 & 25.63 & 34 & 2.85 & 39.94 & 14 & 0.020 & 26 \\
\hline 27 & $\begin{array}{l}\text { Journal of Service } \\
\text { Research }\end{array}$ & 27 & N/A & N/A & $\mathrm{X}$ & N/A & $\mathrm{N} / \mathrm{A}$ & $\mathrm{X}$ & 0.020 & 27 \\
\hline 28 & $\begin{array}{l}\text { Journal of Marketing } \\
\text { Management }\end{array}$ & 30 & N/A & N/A & $\mathrm{X}$ & $\mathrm{N} / \mathrm{A}$ & $\mathrm{N} / \mathrm{A}$ & $\mathrm{X}$ & 0.019 & 28 \\
\hline 29 & $\begin{array}{l}\text { Journal of Travel } \\
\text { Research }\end{array}$ & 39 & 1.12 & 43.77 & $\mathrm{Z}$ & $\mathrm{N} / \mathrm{A}$ & $\mathrm{N} / \mathrm{A}$ & $\mathrm{X}$ & 0.017 & 29 \\
\hline 30 & \begin{tabular}{|l} 
Journal of \\
International \\
Marketing \\
\end{tabular} & 20 & 1.97 & 39.49 & 189 & 1.67 & 33.34 & 58 & 0.015 & 30 \\
\hline 31 & $\begin{array}{l}\text { Journal of Economic } \\
\text { Surveys }\end{array}$ & 33 & 1.44 & 47.47 & $\mathrm{Z}$ & 0.73 & 24.16 & $\mathrm{Z}$ & 0.014 & 31 \\
\hline 32 & $\begin{array}{l}\text { Australasian } \\
\text { Marketing Journal }\end{array}$ & 22 & N/A & N/A & $X$ & $\mathrm{~N} / \mathrm{A}$ & $\mathrm{N} / \mathrm{A}$ & $X$ & 0.014 & 32 \\
\hline 33 & \begin{tabular}{|l|} 
Journal of Public \\
Policy and Marketing
\end{tabular} & 24 & 0.93 & 22.22 & 13 & $\mathrm{~N} / \mathrm{A}$ & $\mathrm{N} / \mathrm{A}$ & $\mathrm{X}$ & 0.014 & 33 \\
\hline 34 & $\begin{array}{l}\text { Journal of Business } \\
\text { and Industrial } \\
\text { Marketing }\end{array}$ & 51 & 0.59 & 30.28 & 214 & $\mathrm{~N} / \mathrm{A}$ & $\mathrm{N} / \mathrm{A}$ & $\mathrm{X}$ & 0.013 & 34 \\
\hline 35 & $\begin{array}{l}\text { Journal of Marketing } \\
\text { Theory and Practice }\end{array}$ & 28 & 0.78 & 21.78 & 386 & $\mathrm{~N} / \mathrm{A}$ & $\mathrm{N} / \mathrm{A}$ & $\mathrm{X}$ & 0.013 & 35 \\
\hline 36 & \begin{tabular}{|l} 
Journal of Product \\
Innovation \\
Management \\
\end{tabular} & 50 & 2.48 & 124.07 & 67 & 2.65 & 132.50 & 19 & 0.012 & 36 \\
\hline 37 & $\begin{array}{l}\text { Marketing } \\
\text { Intelligence and } \\
\text { Planning } \\
\end{array}$ & 51 & 0.57 & 28.92 & 308 & N/A & $\mathrm{N} / \mathrm{A}$ & $\mathrm{X}$ & 0.012 & 37 \\
\hline 38 & $\begin{array}{l}\text { International Journal } \\
\text { of Wine Marketing }\end{array}$ & 0 & N/A & N/A & $X$ & $\mathrm{~N} / \mathrm{A}$ & $\mathrm{N} / \mathrm{A}$ & $X$ & 0.012 & 38 \\
\hline 39 & $\begin{array}{l}\text { Advances in } \\
\text { Consumer Research }\end{array}$ & 0 & 0.10 & 0.00 & 531 & $\mathrm{~N} / \mathrm{A}$ & N/A & $X$ & 0.012 & 39 \\
\hline 40 & $\begin{array}{l}\text { Journal of Business } \\
\text { Ethics }\end{array}$ & 415 & 1.18 & 487.75 & 249 & 1.02 & 424.55 & 99 & 0.012 & 40 \\
\hline 41 & $\begin{array}{l}\text { Psychology and } \\
\text { Marketing }\end{array}$ & 39 & 1.27 & 49.71 & 91 & $\mathrm{~N} / \mathrm{A}$ & N/A & $X$ & 0.011 & 41 \\
\hline
\end{tabular}




\begin{tabular}{|c|c|c|c|c|c|c|c|c|c|c|}
\hline No. & Journal Name & \begin{tabular}{|c|}
2009 \\
Publn
\end{tabular} & \begin{tabular}{|c|} 
Scopus \\
IF
\end{tabular} & $\begin{array}{l}\text { Scopus } \\
\text { TIF }\end{array}$ & $\begin{array}{c}\text { Scopus } \\
\text { Rank } \\
\text {-ing }\end{array}$ & \begin{tabular}{|c|} 
SSCI \\
IF
\end{tabular} & $\begin{array}{l}\text { SSCI } \\
\text { TIF }\end{array}$ & $\begin{array}{c}\text { SSCI } \\
\text { Rank } \\
\text {-ing }\end{array}$ & $\begin{array}{l}\text { MAG } \\
\text { Score }\end{array}$ & $\begin{array}{c}\text { MAG } \\
\text { Rank } \\
\text {-ing }\end{array}$ \\
\hline 42 & $\begin{array}{l}\text { Journal of Consumer } \\
\text { Marketing }\end{array}$ & 49 & 0.66 & 32.32 & 234 & N/A & $\mathrm{N} / \mathrm{A}$ & $\mathrm{X}$ & 0.011 & 42 \\
\hline 43 & Journal of Finance & 81 & 4.08 & 330.63 & 5 & 4.02 & 325.46 & 5 & 0.011 & 43 \\
\hline 44 & Tourism Economics & 51 & 0.51 & 26.12 & 312 & N/A & $\mathrm{N} / \mathrm{A}$ & $\mathrm{X}$ & 0.011 & 44 \\
\hline 45 & $\begin{array}{l}\text { Journal of Personality } \\
\text { and Social Psychology }\end{array}$ & 154 & 5.15 & 792.77 & $\mathrm{Z}$ & 5.04 & 775.39 & $\mathrm{Z}$ & 0.010 & 45 \\
\hline 46 & Organization Science & 50 & 2.68 & 133.93 & 29 & 2.58 & 128.75 & 21 & 0.010 & 46 \\
\hline 47 & $\begin{array}{l}\text { Journal of Product and } \\
\text { Brand Management }\end{array}$ & 53 & 0.59 & 31.49 & 275 & N/A & N/A & $\mathrm{X}$ & 0.010 & 47 \\
\hline 48 & Event Management & 0 & 0.33 & 0.00 & 510 & $\mathrm{~N} / \mathrm{A}$ & N/A & $\mathrm{X}$ & 0.010 & 48 \\
\hline 49 & $\begin{array}{l}\text { Journal of Marketing } \\
\text { Education }\end{array}$ & 27 & 0.72 & 19.50 & 149 & N/A & $\mathrm{N} / \mathrm{A}$ & $\mathrm{X}$ & 0.010 & 49 \\
\hline 50 & $\begin{array}{l}\text { Journal of Interactive } \\
\text { Marketing }\end{array}$ & 0 & 1.66 & 0.00 & 53 & 0.91 & 0.00 & 112 & 0.009 & 50 \\
\hline 51 & $\begin{array}{l}\text { Asia Pacific Journal } \\
\text { of Marketing and } \\
\text { Logistics }\end{array}$ & 26 & N/A & N/A & $\mathrm{X}$ & N/A & N/A & $\mathrm{X}$ & 0.009 & 51 \\
\hline 52 & $\begin{array}{l}\text { Journal of Hospitality } \\
\text { and Tourism Research }\end{array}$ & 25 & N/A & N/A & $\mathrm{X}$ & $\mathrm{N} / \mathrm{A}$ & N/A & $\mathrm{X}$ & 0.009 & 52 \\
\hline 53 & Business Horizons & 63 & 0.67 & 42.37 & 274 & N/A & N/A & $\mathrm{X}$ & 0.009 & 53 \\
\hline 54 & $\begin{array}{l}\text { International Journal } \\
\text { of Advertising }\end{array}$ & 38 & 0.59 & 22.35 & 610 & 0.79 & 30.06 & 124 & 0.009 & 54 \\
\hline 55 & $\begin{array}{l}\text { Journal of Brand } \\
\text { Management }\end{array}$ & 52 & N/A & $\mathrm{N} / \mathrm{A}$ & $\mathrm{X}$ & N/A & N/A & $\mathrm{X}$ & 0.008 & 55 \\
\hline 56 & Logistics Quarterly & 0 & N/A & N/A & $\mathrm{X}$ & N/A & N/A & $\mathrm{X}$ & 0.008 & 56 \\
\hline 57 & $\begin{array}{l}\text { International Journal } \\
\text { of Retail and } \\
\text { Distribution } \\
\text { Management }\end{array}$ & 57 & 0.77 & 43.85 & 267 & $\mathrm{~N} / \mathrm{A}$ & N/A & $\mathrm{X}$ & 0.008 & 57 \\
\hline 58 & $\begin{array}{l}\text { Journal of Business } \\
\text { and Psychology }\end{array}$ & 28 & 0.62 & 17.38 & 204 & 0.41 & 11.59 & 163 & 0.008 & 58 \\
\hline 59 & $\begin{array}{l}\text { International Journal } \\
\text { of Service Industry } \\
\text { Management }\end{array}$ & 28 & 1.53 & 42.82 & 87 & 0.87 & 24.22 & 117 & 0.008 & 59 \\
\hline 60 & $\begin{array}{l}\text { Journal of Consumer } \\
\text { Behavior }\end{array}$ & 22 & $\mathrm{~N} / \mathrm{A}$ & $\mathrm{N} / \mathrm{A}$ & $\mathrm{X}$ & N/A & $\mathrm{N} / \mathrm{A}$ & $\mathrm{X}$ & 0.008 & 60 \\
\hline 61 & $\begin{array}{l}\text { Journal of Business } \\
\text { Logistics }\end{array}$ & 16 & $\mathrm{~N} / \mathrm{A}$ & N/A & $\mathrm{X}$ & N/A & $\mathrm{N} / \mathrm{A}$ & $\mathrm{X}$ & 0.008 & 61 \\
\hline 62 & $\begin{array}{l}\text { Journal of Personal } \\
\text { Selling and Sales } \\
\text { Management }\end{array}$ & 17 & 0.88 & 15.04 & 160 & N/A & N/A & $\mathrm{X}$ & 0.008 & 62 \\
\hline 63 & $\begin{array}{l}\text { Qualitative Market } \\
\text { Research }\end{array}$ & 25 & 0.56 & 14.00 & 373 & N/A & N/A & $\mathrm{X}$ & 0.007 & 63 \\
\hline 64 & $\begin{array}{l}\text { Health Marketing } \\
\text { Quarterly }\end{array}$ & 24 & 0.03 & 0.65 & 63 & N/A & N/A & $\mathrm{X}$ & 0.007 & 64 \\
\hline 65 & $\begin{array}{l}\text { Journal of } \\
\text { Relationship } \\
\text { Marketing }\end{array}$ & 18 & 0.21 & 3.83 & 497 & N/A & $\mathrm{N} / \mathrm{A}$ & $\mathrm{X}$ & 0.007 & 65 \\
\hline 66 & Journal of Business & 0 & N/A & N/A & $\mathrm{X}$ & N/A & N/A & $\mathrm{X}$ & 0.007 & 66 \\
\hline
\end{tabular}




\begin{tabular}{|c|c|c|c|c|c|c|c|c|c|c|}
\hline No. & Journal Name & $\begin{array}{c}2009 \\
\text { Publn }\end{array}$ & \begin{tabular}{|c|} 
Scopus \\
IF
\end{tabular} & $\begin{array}{l}\text { Scopus } \\
\text { TIF }\end{array}$ & $\begin{array}{c}\text { Scopus } \\
\text { Rank } \\
\text {-ing }\end{array}$ & $\begin{array}{c}\text { SSCI } \\
\text { IF }\end{array}$ & $\begin{array}{l}\text { SSCI } \\
\text { TIF }\end{array}$ & $\begin{array}{c}\text { SSCI } \\
\text { Rank } \\
\text {-ing }\end{array}$ & $\begin{array}{l}\text { MAG } \\
\text { Score }\end{array}$ & $\begin{array}{l}\text { MAG } \\
\text { Rank } \\
\text {-ing }\end{array}$ \\
\hline & Ethics Education & & & & & & & & & \\
\hline 67 & Marketing Theory & 32 & $\mathrm{~N} / \mathrm{A}$ & N/A & $\mathrm{X}$ & $\mathrm{N} / \mathrm{A}$ & $\mathrm{N} / \mathrm{A}$ & $\mathrm{X}$ & 0.007 & 67 \\
\hline 68 & $\begin{array}{l}\text { Journal of Euro- } \\
\text { Marketing }\end{array}$ & 11 & $\mathrm{~N} / \mathrm{A}$ & $\mathrm{N} / \mathrm{A}$ & $\mathrm{X}$ & $\mathrm{N} / \mathrm{A}$ & $\mathrm{N} / \mathrm{A}$ & $\mathrm{X}$ & 0.007 & 68 \\
\hline 69 & $\begin{array}{l}\text { Journal of Retailing } \\
\text { and Consumer } \\
\text { Services }\end{array}$ & 57 & $\mathrm{~N} / \mathrm{A}$ & $\mathrm{N} / \mathrm{A}$ & 271 & $\mathrm{~N} / \mathrm{A}$ & $\mathrm{N} / \mathrm{A}$ & $\mathrm{X}$ & 0.007 & 69 \\
\hline 70 & $\begin{array}{l}\text { International Journal } \\
\text { of Hospitality } \\
\text { Management }\end{array}$ & 107 & $\mathrm{~N} / \mathrm{A}$ & $\mathrm{N} / \mathrm{A}$ & $\mathrm{X}$ & N/A & $\mathrm{N} / \mathrm{A}$ & $\mathrm{X}$ & 0.007 & 70 \\
\hline 71 & $\begin{array}{l}\text { Journal of Business to } \\
\text { Business Marketing }\end{array}$ & 9 & 0.76 & 6.81 & $\mathrm{X}$ & N/A & N/A & $\mathrm{X}$ & 0.006 & 71 \\
\hline 72 & $\begin{array}{l}\text { International } \\
\text { Economic Review }\end{array}$ & 45 & 1.15 & 51.62 & $\mathrm{Z}$ & 1.15 & 51.75 & $\mathrm{Z}$ & 0.006 & 72 \\
\hline 73 & $\begin{array}{l}\text { Sloan Management } \\
\text { Review }\end{array}$ & 25 & $\mathrm{~N} / \mathrm{A}$ & $\mathrm{N} / \mathrm{A}$ & $\mathrm{X}$ & $\mathrm{N} / \mathrm{A}$ & $\mathrm{N} / \mathrm{A}$ & $\mathrm{X}$ & 0.006 & 73 \\
\hline 74 & $\begin{array}{l}\text { Journal of Selling and } \\
\text { Major Account } \\
\text { Management }\end{array}$ & 0 & $\mathrm{~N} / \mathrm{A}$ & $\mathrm{N} / \mathrm{A}$ & $\mathrm{X}$ & $\mathrm{N} / \mathrm{A}$ & $\mathrm{N} / \mathrm{A}$ & $\mathrm{X}$ & 0.006 & 74 \\
\hline 75 & Sustainable Tourism & 0 & N/A & N/A & $\mathrm{X}$ & $\mathrm{N} / \mathrm{A}$ & $\mathrm{N} / \mathrm{A}$ & $\mathrm{X}$ & 0.006 & 75 \\
\hline 76 & $\begin{array}{l}\text { Journal of } \\
\text { Occupational Health } \\
\text { Psychology }\end{array}$ & 34 & 2.53 & 86.13 & $\mathrm{Z}$ & 1.91 & 65.08 & $\mathrm{Z}$ & 0.006 & 76 \\
\hline 77 & $\begin{array}{l}\text { American Economic } \\
\text { Review }\end{array}$ & 224 & 2.27 & 508.35 & $\mathrm{Z}$ & 2.29 & 511.84 & $\mathrm{Z}$ & 0.006 & 77 \\
\hline 78 & Management Review & 0 & $\mathrm{~N} / \mathrm{A}$ & $\mathrm{N} / \mathrm{A}$ & $\mathrm{X}$ & $\mathrm{N} / \mathrm{A}$ & $\mathrm{N} / \mathrm{A}$ & $\mathrm{X}$ & 0.006 & 78 \\
\hline 79 & $\begin{array}{l}\text { Journal of World } \\
\text { Business }\end{array}$ & 40 & 1.58 & 63.19 & 171 & 1.52 & 60.96 & 62 & 0.006 & 79 \\
\hline 80 & $\begin{array}{l}\text { Journal of Media and } \\
\text { Economics }\end{array}$ & 13 & 0.48 & 6.24 & $\bar{X}$ & $\mathrm{~N} / \mathrm{A}$ & $\mathrm{N} / \mathrm{A}$ & $\bar{X}$ & 0.006 & 80 \\
\hline 81 & $\begin{array}{l}\text { Journal of Current } \\
\text { Issues and Research in } \\
\text { Advertising }\end{array}$ & 0 & $\mathrm{~N} / \mathrm{A}$ & $\mathrm{N} / \mathrm{A}$ & $\mathrm{X}$ & $\mathrm{N} / \mathrm{A}$ & $\mathrm{N} / \mathrm{A}$ & $\mathrm{X}$ & 0.006 & 81 \\
\hline 82 & $\begin{array}{l}\text { Journal of Global } \\
\text { Marketing }\end{array}$ & 23 & 0.10 & 2.30 & 377 & $\mathrm{~N} / \mathrm{A}$ & $\mathrm{N} / \mathrm{A}$ & $\mathrm{X}$ & 0.006 & 82 \\
\hline 83 & $\begin{array}{l}\text { Journal of Promotion } \\
\text { Management }\end{array}$ & 25 & 0.12 & 2.94 & 398 & $\mathrm{~N} / \mathrm{A}$ & $\mathrm{N} / \mathrm{A}$ & $\mathrm{X}$ & 0.006 & 83 \\
\hline 84 & $\begin{array}{l}\text { Journal of Applied } \\
\text { Psychology }\end{array}$ & 117 & 4.27 & 499.48 & $\mathrm{Z}$ & 3.77 & 440.97 & Z & 0.006 & 84 \\
\hline 85 & British Food Journal & 78 & 0.64 & 50.27 & $\mathrm{Z}$ & $\mathrm{N} / \mathrm{A}$ & $\mathrm{N} / \mathrm{A}$ & $\mathrm{X}$ & 0.005 & 85 \\
\hline 86 & $\begin{array}{l}\text { International Business } \\
\text { Review }\end{array}$ & 48 & 1.07 & 51.20 & 184 & 1.20 & 57.60 & 82 & 0.005 & 86 \\
\hline 87 & $\begin{array}{l}\text { Journal of } \\
\text { Management }\end{array}$ & 60 & 3.82 & 229.46 & 45 & 3.08 & 184.80 & 10 & 0.005 & 87 \\
\hline 88 & \begin{tabular}{|l} 
Journal of \\
Management Studies
\end{tabular} & 58 & 2.92 & 169.60 & 68 & 2.56 & 148.36 & 23 & 0.005 & 88 \\
\hline 89 & $\begin{array}{l}\text { Quantitative } \\
\text { Marketing and } \\
\text { Economics }\end{array}$ & 11 & 1.23 & 13.48 & 298 & $\mathrm{~N} / \mathrm{A}$ & $\mathrm{N} / \mathrm{A}$ & $\mathrm{X}$ & 0.005 & 89 \\
\hline
\end{tabular}




\begin{tabular}{|l|l|c|c|c|c|c|c|c|c|c|}
\hline No. & Journal Name & $\begin{array}{c}\mathbf{2 0 0 9} \\
\text { Publn }\end{array}$ & $\begin{array}{c}\text { Scopus } \\
\text { IF }\end{array}$ & $\begin{array}{c}\text { Scopus } \\
\text { TIF }\end{array}$ & $\begin{array}{c}\text { Scopus } \\
\text { Rank } \\
- \text { ing }\end{array}$ & $\begin{array}{c}\text { SSCI } \\
\text { IF }\end{array}$ & $\begin{array}{c}\text { SSCI } \\
\text { TIF }\end{array}$ & $\begin{array}{c}\text { SSCI } \\
\text { Rank } \\
\text {-ing }\end{array}$ & $\begin{array}{c}\text { MAG } \\
\text { Score }\end{array}$ & $\begin{array}{c}\text { MAG } \\
\text { Rank } \\
\text {-ing }\end{array}$ \\
\hline 90 & $\begin{array}{l}\text { Journal of Sustainable } \\
\text { Tourism }\end{array}$ & 42 & 1.23 & 51.61 & 216 & N/A & N/A & X & 0.005 & 90 \\
\hline 91 & $\begin{array}{l}\text { Service Industries } \\
\text { Journal }\end{array}$ & 107 & 0.50 & 53.50 & 352 & 0.45 & 48.36 & 160 & 0.005 & 91 \\
\hline 92 & Tourism Review & 12 & N/A & N/A & X & N/A & N/A & X & 0.005 & 92 \\
\hline 93 & $\begin{array}{l}\text { Journal of Vacation } \\
\text { Marketing }\end{array}$ & 20 & N/A & N/A & X & N/A & N/A & X & 0.005 & 93 \\
\hline 94 & $\begin{array}{l}\text { Marketing Education } \\
\text { Review }\end{array}$ & 13 & N/A & N/A & X & N/A & N/A & X & 0.005 & 94 \\
\hline 95 & $\begin{array}{l}\text { Journal of Business } \\
\text { Venturing }\end{array}$ & 40 & 2.68 & 107.16 & 59 & 2.14 & 85.72 & 35 & 0.005 & 95 \\
\hline 96 & $\begin{array}{l}\text { Management } \\
\text { International Review }\end{array}$ & 32 & 0.79 & 25.17 & 303 & N/A & N/A & X & 0.004 & 96 \\
\hline 97 & $\begin{array}{l}\text { Consumption Markets } \\
\text { and Culture }\end{array}$ & 12 & N/A & N/A & X & N/A & N/A & X & 0.004 & 97 \\
\hline 98 & $\begin{array}{l}\text { Current Issues in } \\
\text { Tourism }\end{array}$ & 30 & 0.98 & 29.46 & 371 & N/A & N/A & X & 0.004 & 98 \\
\hline 99 & $\begin{array}{l}\text { The Marketing } \\
\text { Review }\end{array}$ & 18 & N/A & N/A & X & N/A & N/A & X & 0.004 & 99 \\
\hline 100 & $\begin{array}{l}\text { Journal of Nonprofit } \\
\text { Mark Public Sector }\end{array}$ & 15 & 0.17 & 2.57 & 483 & N/A & N/A & X & 0.004 & 100 \\
\hline Marketing & & & & & & & \\
\hline
\end{tabular}

Note: $\mathrm{Z}=$ Journals not in Business Category; X: No information is available for this journal; Subject Category Analyzed: Business and Management; IF: Impact Factor; TIF: Total Impact Factor

\section{Conclusions}

Across the world, researchers debate the issue of journal rankings and the measurement of academic performance based on such rankings. This debate has led researchers to question the measures used in such rankings (Adler and Harzing, 2009; Rynes, 2007; Segalla, 2008). This study used the vox populi approach to explore how marketing academics across the spectrum rank academic journals. The findings highlight several important aspects related to (1) the development of the MAG score, which captures how academics themselves rank journals; (2) top-of-the-mind recall of journals academics want to publish in; (3) regional preferences among academics regarding the top journals and their publications pattern; and (4) comparison of the MAG score with other established measures (i.e., SSCI and Scopus) to augment the current assessment of journal rankings. The findings should help active researchers identify journals that are highly ranked among their peer groups and, in turn, increase their publication visibility. The findings should also help university managers, administrators, and policy makers understand the "collective psyche" of marketing academics across the globe and make better judgments about tenure, grants, and employment decisions.

The commonalities and distinctions between the MAG score and the other measures suggest the need for caution in employing any single journal ranking list in isolation 
for decision making. Scopus focuses on broader management journals, while the MAG score focuses highly on the marketing, tourism, and international business journals. However, the highly significant correlation between overall as well as the top 20 journals in Scopus and the MAG score suggests that decision makers can use these lists as complementary to each other. Such complementarity will assist more informed decision making in evaluating marketing scholarship among academics around the world.

Researchers who seek visible reputation and financial rewards in their academic careers experience pressures to follow the rules of research committees, many of which use the journal rankings as a barometer of an individual's success. Many scholars have identified such rankings as arbitrary and have criticized them for their top-heavy approach (e.g., Adler and Harzing, 2009), in which only senior academics are involved in deciding the ranking of the journals (Mort et al., 2004). The approach this study uses captures a wide spectrum of academics (see Mort et al., 2004; Perren et al., 2001) and, as such, provides a balanced ranking. Although the vox populi approach has not been used previously to examine journal rankings, the significant correlation with Scopus suggests that the MAG score is a robust measure for journal rankings. The strong correlation between the measures also provides the evidence that results developed from academic perceptions about journal rankings are as good an indicator as the bibliometrics that Scopus or SSCI provides.

The comparative findings from Scopus and the MAG score show the popularity of U.S. journals over others. As both measures are global in nature, this study can conclude that the top journals with global influence in academic circles are primarily of U.S. origin. Of the top 10 journals, eight are U.S. based and two are European based. This demonstrates the significant influence of U.S. academic and professional bodies on the marketing discipline on a global scale. As for the European journals among the top 10, the International Journal of Research in Marketing is the official journal of the European Marketing Academy, which represents the largest body of European marketing academics. However, European Journal of Marketing is not tied to an association and is the only journal with a regional association title.

Among the top 10 Scopus journals in the management field, five relate to the field of marketing, of which four also are represented in the MAG score. Journal of Public Policy \& Marketing is ranked 33 in the MAG score list. In addition, only one general business-related journal appears in the top 10 (i.e., Journal of Business Research) of the MAG score. The other nine journals strongly focus on the marketing discipline. The study results show a clear preference among marketing academics toward journals that focus on the marketing discipline only. This lower recall as well as publication preference toward broader management journals is alarming. Most journal rankings regard journals such as Academic of Management Journal, Academy of Management Review, and Administrative Science Quarterly highly. The lower inclination to publish in management journals may be detrimental to the marketing discipline at large. Marketing academics need to change their mindset toward management journals if the field is to obtain broader acceptance among academics from other disciplines as well as practitioners. Changing the current mindset will 
encourage cross-fertilization of ideas that are necessary for a healthy and impactful academic dialogue.

Three issues need further attention. First, according to the journal ranking lists, the top 30 journals are highly established in their respective fields, and following these lists may create a bias among academics toward not publishing in low-rated journals. In this sense, newer journals are particularly disadvantaged (Adler and Harzing, 2009; Lawrence, 2003; Mort et al., 2004). Therefore, future research needs to develop further measurement that focuses on new journals appearing in the field. Second, journal ranking lists themselves are dynamic; they change according to the debate in the field as well as journals' overall impact. In turn, this may affect academic perceptions as well, and therefore perceptual studies should be undertaken on a regular basis. Third, caution should be exercised in following the journal ranking lists alone as a measure for decisions regarding promotion, tenure, and other significant decisions because publication in a high-ranking journal does not specify the quality of the article. As mentioned previously, measures such as citations of an article, peer evaluation, and industry impact should also be considered when making judgments about an academic's scholarship.

\section{References}

Adler, N.J. and Harzing, A.W. (2009), "When knowledge wins: Transcending the sense and nonsense of academic rankings", Academy of Management Learning and Education, vol. 8, no. 1, pp. 72-95.

Bagozzi, R.P. and Silk, A.J. (1983), "Recall, recognition, and the measurement of memory for print advertisements", Marketing Science, vol. 2, no. 2, pp. 95-134.

Bakir, A., Vitell, S.J. and Rose, G.M. (2000), "Publications in major marketing journals: An analysis of scholars and marketing departments", Journal of Marketing Education, vol. 22, no. 2 , pp. 99-107.

Cudd, M. and Morris, J. (1988), "Bias in journal ratings", Financial Review, vol. 23, no. 1, pp. 117-125.

Dibb, S. and Simkin, L. (2005), "Benchmarking the RAE returns of marketing professors' journal publications", Journal of Marketing Management, vol. 21, no. 7, pp. 879-896.

Extejt, M.M. and Smith, J.E. (1990), “The behavioral sciences and management: An evaluation of relevant journals", Journal of Management, vol. 16, no. 3, pp. 539-551.

Finn, A. (1992), "Recall, recognition and the measurement of memory for print advertisements: A reassessment", Marketing Science, vol. 11, no. 1, pp. 95-100.

Galton, F. (1907), “Vox populi”, Nature, vol. 75, pp. 450-451. 
Guerrero, R. (2002), "Misuse and abuse of journal impact factors", European Science Editing, vol. 27 , no. 3 , pp. 58-59.

Hascall, V.C., Bollen, J. and Hanson, R.W. (2007), "Impact factor page rankled", ASBMB Today, pp. 16-19.

Jobber, D. and Simpson, P. (1988), "A citation analysis of selected marketing journals", International Journal of Research in Marketing, vol. 5, no. 2, pp. 137-142.

Kacmar, K.M. and Whitfield, J.M. (2000), "An additional rating method for journal articles in the field of management", Organizational Research Methods, vol. 3, no. 4, pp. 392-406.

Kirkpatrick, S.A. and Locke, E.A. (1992), "The development of measures of faculty scholarship", Group and Organization Management, vol. 17, no. 1, pp. 5-23.

Krugman, H.E. (1986), "Low recall and high recognition of advertising”, Journal of Advertising Research, vol. 26, no. 1, pp. 79-86.

Lange, T. (2006), "The imprecise science of evaluating scholarly performance: Utilizing broad quality categories for an assessment of business and management journals", Evaluation Review, vol. 30, no. 4, 505.

Lawrence, P.A. (2003), "The politics of publication: Authors, reviewers, and editors must act to protect the quality of research", Nature, vol. 422, no. 6929, pp. 259-261.

Macdonald, S. and Kam, J. (2007), "Aardvark et al.: Quality journals and gamesmanship in management studies”, Journal of Information Science, vol. 33, no. 6, pp. 702-717.

Mort, G.S., McColl-Kennedy, J., Kiel, G. and Soutar, G.N. (2004), "Perceptions of marketing journals by senior academics in Australia and New Zealand", Australasian Marketing Journal, vol. 12, no. 2, pp. 51-61.

Perren, L., Berry, A. and Blackburn, R. (2001), "The UK small business research community and its publication channels: Perceptions and ratings", Journal of Small Business and Enterprise Development, vol. 8, no. 1, pp. 76-90.

Rynes, S.L. (2007), “Academy of Management Journal editor's forum on citations: Editor's forward", Academy of Management Journal, vol. 50, no. 3, pp. 489-490.

Saad, G. (2009), "Applying the h-index in exploring bibliometric properties of elite marketing scholars", Scientometrics, vol. 69, no. 1, pp. 117-120.

Segalla, M. (2008), "Publishing in the right place or publishing the right thing: Journal targeting and citations' strategies for promotion and tenure committees", European Journal of International Management, vol. 2, no. 2, 122-127.

Shapiro, S. and Krishnan, H.S. (2001), "Memory-based measures for assessing advertising effects: A comparison of explicit and implicit memory effects", Journal of Advertising, vol. 30, no. 3, pp. 1-13. 
Stapel, J. (1998), "Recall and recognition: A very close relationship", Journal of Advertising Research, vol. 38, no. 4, pp. 41-45.

Surowiecki, J. (2004), The Wisdom of Crowds: Why the Many Are Smarter Than the Few and How Collective Wisdom Shapes Business, Economies, Societies, and Nations, Doubleday Books, New York, NY.

Theoharakis, V. and Hirst, A. (2002), "Perceptual differences of marketing journals: A worldwide perspective", Marketing Letters, vol. 13, no. 4, pp. 389-402.

Till, B.D. and Baack, D.W. (2005), "Recall and persuasion: Does creative advertising matter? Journal of Advertising, vol. 34, no. 3, pp. 47-57.

Todorov, R. and Glanzel, W. (1988), "Journal citation measures: A concise review”, Journal of Information Science, vol. 14, no. 1, pp. 47-56.

Van Fleet, D.D., McWilliams, A. and Siegel, D.S. (2000), "A theoretical and empirical analysis of journal rankings: The case of formal lists", Journal of Management, vol. 26, no. 5, pp. 839-861. 